\title{
Religious control to decrease auditor turnover in public accountant firms in Indonesia
}

\author{
Heru Sulistiyo ${ }^{a^{*}}$, Putu Sulastria and Alex Sujanto ${ }^{\mathrm{b}}$
}

${ }^{a}$ STIE Dharmaputra Semarang, Indonesia

${ }^{b}$ AMIK Jakarta Teknologi Cipta Semarang, Indonesia

\begin{tabular}{l}
\hline C H R O N I C L E \\
\hline Article history: \\
Received: July 28, 2020 \\
Received in revised format: \\
July 302020 \\
Accepted: September 6, 2020 \\
Available online: \\
September 11, 2020 \\
\hline Keywords: \\
Professional commitment \\
Organizational commitment \\
Religious control and turnover
\end{tabular}

Religious control and turnover

\begin{abstract}
A B S T R A C T
Highly qualified auditors have been considered essential in an accountant firm; however, the higher their competence are, the higher the tendency they move to another organization. The aim of the research was to analyze the role of religious control in mediating the effects of professional commitment and organizational commitment to auditors' turnover working in public accountant firms in Indonesia. The research sample was 401 respondents chosen by accidental sampling based on their answers sent by emails. The tool of analysis was structural equations model calculated by using SPSS program. The results show that religious control reduced auditors' turnover directly and mediated the effect of professional commitment on auditors' turnover. Professional commitment and organizational commitment could not reduce auditor turnover, and religious control was not able to mediate the influence of organizational commitment on turnover of the auditors. The theoretical implications of this research enriching behavioral accounting and auditing literature and the practical implications of giving policy consideration to the head of the public accounting firm.
\end{abstract}

\section{Introduction}

As high turnover affects the increase of expenses, productivity lost, increase of time and expenses of recruiting new workers, the turnover phenomenon of auditors working on public accounting firms (PAF) has become a central issue, since auditors are not only important human capital for PAF, but also the relationship with their clients is based on trust and confidentiality. To understand about it, Aries and Ghozali (2006) categorized voluntary turnover as a form of dysfunctional behavior, and as most PAFs experience the voluntary turnover, it has become a threat. They further explained that voluntary turnover is often seen as a "disease" in public accounting profession, as clients and partners often complain that their works are done by new and less experienced employees. Meanwhile, functional turnover carried out by employees having low performance are less reliable and they may overload and disturb their colleagues. In this case, professional turnover is considered to be an opportunity for highly capable employees to substitute those who are leaving. Several findings showed that turnover of professionals in PAF is quite high (Snead \& Harrell, 1991) proven by the facts that the turnover rate of auditors working in big PAFs was 85 percent (Kollaritsh in Ratnawati, 2001), the turnover of auditor at non-partner levels working in PAF was $45 \%$, the turnover rate of junior (staff) auditors with one to three years of experiences working in PAFs was 23.9\% per year (Lampe \& Earnest, 1984), and, in 2016, the turnover of auditors working in PAFs in Indonesia was 56.3\% (Sulistiyo, 2017). Considering this phenomenon, Scholl (1981) proposed to take the relationship between expectation theory and organizational commitment in a $2 \times 2$ matrix model into consideration. This model could be applied to analyze employee's intention either to keep working or leaving. 
Employees who have low expectations and low organizational commitment would intend to leave the organization. Meanwhile, employees who have high expectations with high or low commitment tend to stay in the organization or have a low intention to leave. The results of previous studies proved that organizational commitment has a significantly negative effect on outgoing intentions (Lim et al., 2017; Cannon \& Herda., 2016; Janah et al., 2016; Nouri \& Parker, 2013). The negative influence indicated that if the commitment is high, the intention to leave will be low. The reason is that the auditors is still willing to accept and struggle for keeping the values and goals of the organization. On the other hand, different result proposed by Rageb, Salam, Samadicy, and Farid (2013) showed that organizational commitment positively but not significantly affects the intention to leave. This finding meant that if organizational commitment increased, the intention to leave would also increase, but the increase was not significant, which was probably caused by more promising outside work offerings. In addition, Sow (2015) proved that continuance and normative organizational commitment negatively but not significantly affect turnover intention; which is probably caused by better alternatives jobs are available. The existence of business phenomena and the results of different studies underlay the proposed study to discover solutions that might solve these differences by the mediation of religious control. The argument are that:

a. As commitments can improve self-control, the intention to leave the organization will decrease.

b. Self-control as a manifestation of religious values is the strongest one; as it comes from God Almighty.

c. Religious plays an important role in preventing deviant behavior as proposed by Cohran (1988), Shyam et al. (2002), Desmond et al. (2013), Danuri and Sulistiyo (2017), and Sulistiyo and Ghozali (2017).

Given this situation, this study empirically examined the role of religious control in mediating the influence of professional commitment and organizational commitment on the turnover of auditors working in the Indonesian Public Accounting Firm.

\section{Literature Review and Hypotheses}

\subsection{Effect of Commitment on Religious Control}

There are three types of employees' commitments; organizational commitment, career commitment, and work commitment (Muthuveloo \& Che, 2005). According to Cook and Wall (1980), organizational commitment is an affective reaction of an employee to the characteristics of his/her organization. The reaction is associated with the feeling of being attached to the purposes and the values of the organization and to the organizational improvement. Meanwhile, according to Aranya et al. (1981), professional commitment is to trust in and accept to the professional goals and values, a willingness to truly strive for professional interests, and the desire to maintain membership in the profession. Among the elements of the commitment was the attachment to the values of the organization or profession; therefore, the higher the commitment of an employee was, the more bound he/she would be to the values and would be fight for them. More than that, a value will motivate behavior, solves conflicts, and guides individuals in taking certain positions and evaluating them (Alfan, 2013). Religious control is a religious environment enable of influencing the attitude and behavior of one's religiosity (Sulistiyo \& Ghozali, 2017). Within the religious environment, religious values are applied to everyday life, so as to cultivate one's self-control based religion. This is in line with the results of the study of Carter et al. (2012) suggesting that religious people have great self-control because they feel that there is a high power watching over them; God. In addition, it is also in accordance with the Parliament of the World's Religions (1993) stating that the spiritual power of religion offers the basis of trust, meaning or basic values, and the highest standards for the welfare and respect of the entire community of living beings (humans, animals, and plants). Therefore, if a commitment tied to the attachment of the value was linked to the religious values, it could be predicted that the higher the person's commitment was, the higher the religious control they might have. Thus, the first and second hypotheses are formulated as follows.

$\mathrm{H}_{1}$ : Professional commitment has a positive effect on religious control.

$\mathrm{H}_{2}$ : Organizational commitment has a positive effect on religious control.

\subsection{Effect of Auditor Commitment on Auditors Turnover}

Scholl (1981) proposed a relationship between expectation theory and organizational commitment in a $2 \times 2$ matrix model.

\section{Table 1}

Expectations, Commitments, and Decisions to Stay in the Organization

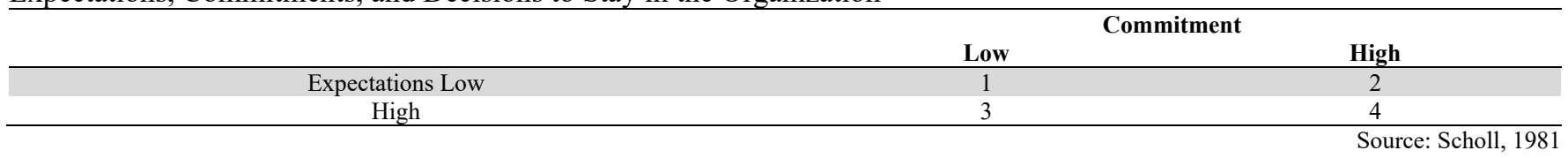


He further explained that, in this model, high expectations are indicated by the existence of performance appraisals, high appreciation, and dignity. Meanwhile, a high commitment is indicated by employees' high investments in their work (contribution of efforts for the organization progress), reciprocity (dependence relationship and mutual assistance), the absence of alternatives to exit and identification (clarity of organizational values and objectives). Table 1 shows reasons and tendency of employees either to stay or to leave the organization. Employees in box 1 are those who have a tendency to quit their jobs because of low expectations and low commitment. Employees in boxes 2, 3, and 4 have a tendency to stay in the organization for various reasons. Employees resigning from an organization is called turnover. Employee turnover is a permanent resignation of an employee from an organization voluntarily or involuntarily (Robbins and Judge, 2013). In order to deal with this problem, professional commitment can be used as a tool to measure whether an employee will remain or leave the organization (Bagraim, 2003). In this case, employees having highly organizational commitment will be more motivated to be present in the organization and try to achieve the organizational goals (Cook \& Wall, 1980). In a broader perspective, employees holding organizational commitment is beneficial to reduce the level of employee turnover and increase the quantity as well as quality of work productivity (Mathieu \& Zajac, 1990). On the basis of the explanation, hypotheses 3 and 4 are formulated as follows:

$\mathrm{H}_{3}$ : Professional commitment has a negative effect on auditor turnover.

$\mathrm{H}_{4}$ : Organizational commitment has a negative effect on auditor turnover.

\subsection{Effect of Religious Control on Auditor Turnover}

As religious prevents deviant behavior (Cohran, 1988; Shyam et al., 2002; Desmond et al., 2013), highly religious people tend to have bigger self- control since they believe that there is a power of the Highest (The God) overseeing them (Carter, McCullough, \& Carver, 2012). Therefore, religious control decreases dysfunctional audit behavior (Sulistiyo \& Ghozali, 2017). In this case, voluntary turnover is considered a form of dysfunctional behavior, and as most PAFs experience the voluntary turnover, it becomes a threat. Thus, voluntary dysfunctional turnover is often regarded as a "disease" in the public accounting profession. The explanation suggested that the role of the religious control on the turnover was predicted to reduce the auditors' turnover; therefore, hypothesis 5 is formulated as follows:

$\mathrm{H}_{5}$ : Religious control has a negative effect on auditor turnover.

\subsection{Religious Control Mediates the Effect of Commitment to Auditor Turnover}

Based on the hypotheses 1, 2, and 5, it could be predicted that auditors who have high commitment as well as improved selfcontrol, their desire to leave the organization will decrease. Therefore, hypotheses 6 and 7 are formulated as follows:

$\mathrm{H}_{6}$ : Religious Control mediates the effect of Professional Commitment on Auditor Turnover.

$\mathrm{H}_{7}$ : Religious Control mediates the effect of Organizational Commitment on Auditor Turnover.

\section{Empirical Research Model}

On the basis of the literatures, the empirical research model developed is illustrated in Fig. 1.

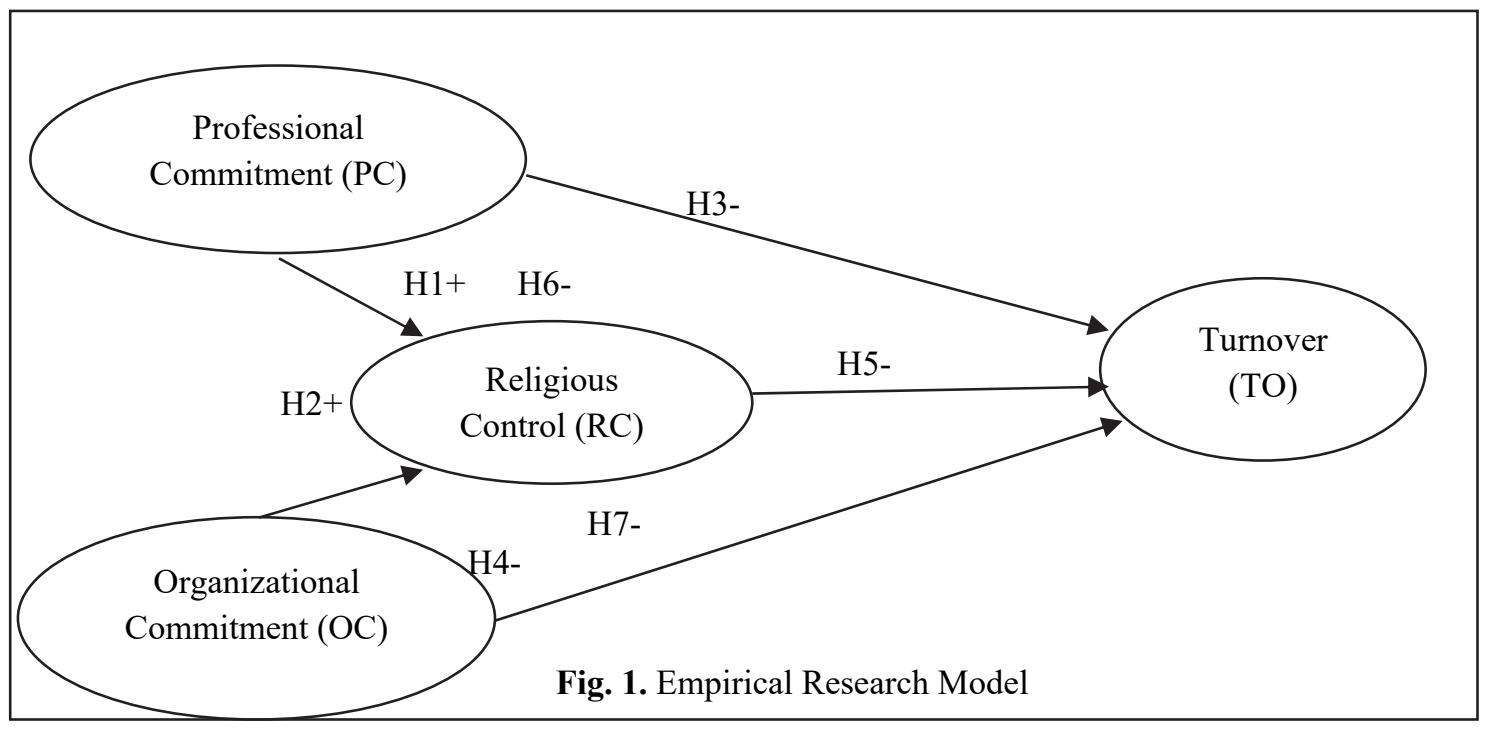


Fig. 1 shows the prediction that if professional commitment and organizational commitment increase religious control, the auditor turnover will decrease.

\section{Research Methods}

\subsection{Sample Design}

The population in this study were auditors working in PAFs throughout Indonesia; yet, no data were available regarding the numbers of them. The available data collected were 525 city-based PAF (Directory of Public Accountants - IAPI, 2016), based on which the questionnaires were sent by email to every PAF. Among 552 returned emails, 497 were valid, consisting of 414 auditors and 83 PAF head offices. The unit of analysis was the auditors; thus, the data of the PAF head offices were not used. As 13 data turned out to be extreme, the final data analyzed were 401.

\subsection{Research Variables, Operational Definitions, and Measurements}

Professional commitment is trust and acceptance upon the goals and values of the profession, a willingness to use a genuine effort for professional interests, and a desire to maintain membership in the profession (Aranya et al., 1981). Professional commitment can be measured by assessing its relative strength to identify the professional involvement of a person, to what extent he/she cares and dedicates for an expression, and proud to be the member of the profession (Suddaby et al., 2009). Professional commitment is measured by 8 statements adopted from Aranya et al. (1981) and Suddaby et al. (2009). Meanwhile, organizational commitment refers to an affective reaction of a person to his/her organization characteristics, an attachment feeling to the purpose and organizational values, and a willingness to develop the organization performance (Cook \& Wall, 1980). Organizational commitment is characterized by three factors: strong beliefs and acceptance to the organizational goals and values, willingness to put effort for the organization, and desire to maintain organizational membership (Robbins \& Judge, 2013). Previously, Suddaby et al. (2009) proposed an organizational commitment in term of the involvement of an employee to care, dedicate, and be proud of being a member of an organization. Religious control is a religious environment that can influence one's religious attitudes and behavior (Sulistiyo \& Ghozali, 2017). Religious control indicators include religious office environment, religious family environment, religious living environment, religious social environment, and religious ideological environment. The indicator is measured by 16 statements from Sulistiyo and Ghozali (2017). Turnover, on the other hand, is the permanent resignation of an employee from an organization voluntarily or involuntarily (Robbins \& Judge, 2013). In this study, turnover was measured by the number of organizations an auditors had worked in. Score 1 meant that the auditor only worked in one organization and he/she never moved to another organization. Score 2-7 showed that an auditor had experienced in working in 2 to 7 organizations. Meanwhile, the variables of Professional Commitment, Organizational Commitment, and Religious Control were measured by Likert scale scoring from 1 to 7 ; showing the degree of very disagree/low to very agree/high.

\subsection{Analysis Method}

Structural equations method (SEM) is used to analyze the data.

$$
\begin{aligned}
& R C=b_{1} P C+b_{2} O C+e_{1}, \\
& T O=b_{3} P C+b_{4} O C+b_{5} R C+e_{2},
\end{aligned}
$$

where RC, PC, OC, TO represent Religious Control, Professional Commitment, Organizational Commitment and Turnover, respectively. Also, $b_{1}$ to $b_{5}$ represent the coefficients to be estimated. Finally, $e_{1}$ and $e_{2}$ are residuals.

\section{Results and Discussion}

\subsection{Questionnaire Testing}

The result of the Cronbach alpha test upon the research questionnaire was $>0.7$ for reliability, and the correlation (r) count is greater than $r$ table for validity (Ghozali, 2011). The results of the reliability and validity test showed that the questionnaire was reliable and valid as shown in the following Table 2 and Table 3.

Table 2

Reliability Test Results

\begin{tabular}{lcc}
\hline \multicolumn{1}{c}{ Variable } & Cronbach Alpha value & Status \\
\hline Professional Commitment (PC) & 0.872 & Reliable \\
Organizational Commitment (OC) & 0.887 & Reliable \\
Religious Control (RC) & 0.944 & Reliable \\
\hline
\end{tabular}


Table 3

Validity Test Results

\begin{tabular}{lcc}
\multicolumn{1}{c}{ Variable } & "R" Count & "R" Table (5\%, df 400 two sides) \\
\hline Professional Commitment (PC1-PC8) & $0.490-0.763$ & 0.098 \\
Organizational Commitment (OC1-OC8) & $0.599-0,720$ & 0.098 \\
Religious Control (RC1-RC16) & $0.365-0,766$ & 0.098 \\
\hline
\end{tabular}

\subsection{Fit Model Testing}

Fit model test using multiple linear regression was applied to analyze the data as shown in Table 4 and Table 5 .

Table 4

ANOVA results for Eq. (1)

\begin{tabular}{|c|c|c|c|c|c|c|}
\hline & Model & Sum of Squares & df & Mean Square & $\mathbf{F}$ & Sig. \\
\hline \multirow[t]{3}{*}{1} & Regression & 289,255 & 2 & 144.627 & 120,638 & $.000^{\mathrm{a}}$ \\
\hline & Residual & 477,146 & 398 & 1,199 & & \\
\hline & Total & 766,401 & 400 & & & \\
\hline
\end{tabular}

a. Predictors: (Constant), OC, PC

b. Dependent Variable: RC

Table 5

ANOVA results for Eq. (2)

\begin{tabular}{ccccccc}
\hline & Model & Sum of Squares & Df & Mean Square & F & Sig. \\
\hline 1 & Regression & 27,884 & 3 & 9,295 & 2.696 & \\
& Residual & 1368,744 & 397 & 3,448 & & \\
& Total & 1396,628 & 400 & & \\
\end{tabular}

a. Predictors: (Constant), RC, OC, PC

b. Dependent Variable: TO

The results of the fit model test using multiple linear regression exhibited in Table 4 and Table 5 showed that the sig value of the equation 1 was 0.000 , which was less than 0.05 , and that of the equation 2 was 0.046 , which was less than 0.05 . Thus, the model was suitable to predict the influence of the independent variable on the dependent variable modeled.

\subsection{Hypothesis Testing}

Furthermore, the result of the test on hypotheses 1 and 2 is presented in table 6.

Table 6

Coefficients Equation $1^{\text {a }}$

\begin{tabular}{|c|c|c|c|c|c|c|c|c|}
\hline & \multirow[b]{2}{*}{ Model } & \multicolumn{2}{|c|}{$\begin{array}{l}\text { Unstandardized } \\
\text { Coefficients }\end{array}$} & \multirow{2}{*}{$\begin{array}{c}\text { Standardized } \\
\text { Coefficients } \\
\text { Beta } \\
\end{array}$} & \multirow[b]{2}{*}{$\mathrm{T}$} & \multirow[b]{2}{*}{ Sig. } & \multicolumn{2}{|c|}{ Collinearity Statistics } \\
\hline & & B & Std. Error & & & & Tolerance & VIF \\
\hline \multirow[t]{3}{*}{1} & (Constant) & 1,921 & .260 & & 7.401 & .000 & & \\
\hline & $\mathrm{PC}$ & .558 & .036 & .611 & 15,327 & .000 & .984 & 1.017 \\
\hline & $\mathrm{OC}$ & -.019 & .036 & -.021 & -.537 & .591 & .984 & 1.017 \\
\hline
\end{tabular}

a. Dependent Variable: RC

The results of the test on hypotheses 1 and 2, as presented in Table 6 , showed that the value of the sig PC was 0.000 , which was less than 0.05 , and the regression coefficient was 0.611 positive; meaning that professional commitment increase religious control, so the hypothesis 1 was accepted. The logical reason proposed was that an auditor who was committed to his profession would be willing to increase his religious control in order to level the suitability of values. The value of the sig OC was 0.591 , which was greater than 0.05 and the regression coefficient was 0.021 negative; meaning that the organizational commitment had significant negative effect on religious control, thus hypothesis 2 was rejected. The logical reason underline was that the auditor who had high organizational commitment contributed higher proportion of his/her time for the progress of the organization. As a result, time spent for religious activities would be reduced leading to the decrease of the religious control; even though, the decline was not significant. 
Coefficients Equation $2^{\mathrm{a}}$

\begin{tabular}{|c|c|c|c|c|c|c|c|c|}
\hline & \multirow[b]{2}{*}{ Model } & \multicolumn{2}{|c|}{$\begin{array}{l}\text { Unstandardized } \\
\text { Coefficients }\end{array}$} & \multirow{2}{*}{$\begin{array}{c}\text { Standardized } \\
\text { Coefficients } \\
\text { Beta }\end{array}$} & \multirow[b]{2}{*}{$\mathrm{t}$} & \multirow[b]{2}{*}{ Sig. } & \multicolumn{2}{|c|}{ Collinearity Statistics } \\
\hline & & $\mathrm{B}$ & Std. Error & & & & Tolerance & VIF \\
\hline \multirow[t]{4}{*}{1} & (Constant) & 1,836 & .469 & & 3,912 & .000 & & \\
\hline & PC & .154 & .078 & .125 & 1974 & .049 & .619 & 1,617 \\
\hline & $\mathrm{OC}$ & .15 & .60 & .12 & .248 & .804 & .983 & 1.017 \\
\hline & $\mathrm{RC}$ & -.239 & .085 & -.177 & $-2,810$ & .005 & .623 & 1,606 \\
\hline
\end{tabular}

a. Dependent Variable: TO

Table 7 exhibits the results of the test upon hypotheses 3,4 , and 5, showing that the value of the PC sig was 0.049 , which was smaller than 0.05 , and the regression coefficient was positive at 0.125 . These values meant that professional commitment increased auditor turnover; thus hypothesis 3 was rejected. The logical reason was that highly professional auditors would also have highly bargaining power to other workplaces leading to the state that the rate of auditors' moving to other workplaces increased. The increased opportunity to move was accommodated by the fact that other workplaces were also in need of professional auditors to guarantee the quality of the audit work. Moreover, the value of the OC sig was 0.804 , which was greater than 0.05 , and the regression coefficient was 0.248 positive. The meaning was that the organizational commitment increased turnover; thus hypothesis 4 was rejected. The logical reasons were exactly the same as the one of the professional commitments. Furthermore, as the unit of analysis of this study was professional auditors, in general, they would be more committed to their profession than their organizations. This finding was in line with the turnover phenomenon of the Indonesian PAF auditors revealing that $56.3 \%$ of auditors had moved to other organizations (Sulistiyo, 2017). In addition, the value of the RC sig was 0.005 , which was smaller than 0.05 , and the regression coefficient was 0.177 negative. These values proved that the religious control decreased auditor turnover; thus hypothesis 5 was accepted. The logical reason was that the higher the religious based control of a person was, the higher the deviant behavior will be avoided. For people holding a strong believe in a religion, leaving or moving to other workplaces was considered deviant behavior, as he/she showed less gratitude for what he/she had been received and a form of disloyalty towards the organization, which might encourage the organization owner issued a negative assessment upon him. Therefore, the higher the religious control of an auditor was, the less the desire of an auditor to change jobs would be. These results were in line with previous one revealing that religion played an important role in preventing deviant behavior (Cohran, 1988; Shyam et al., 2002; Desmond et al., 2013; Danuri \& Sulistiyo, 2017) and dysfunctional audits (Sulistiyo \& Ghozali, 2017). Hypothesis 6 and 7 were tested using online test of Sobel provided in the web site https://www.danielsoper.com/statcalc/calculator.aspx?id=31, and the results are presented in Fig. 2 and Fig. 3.

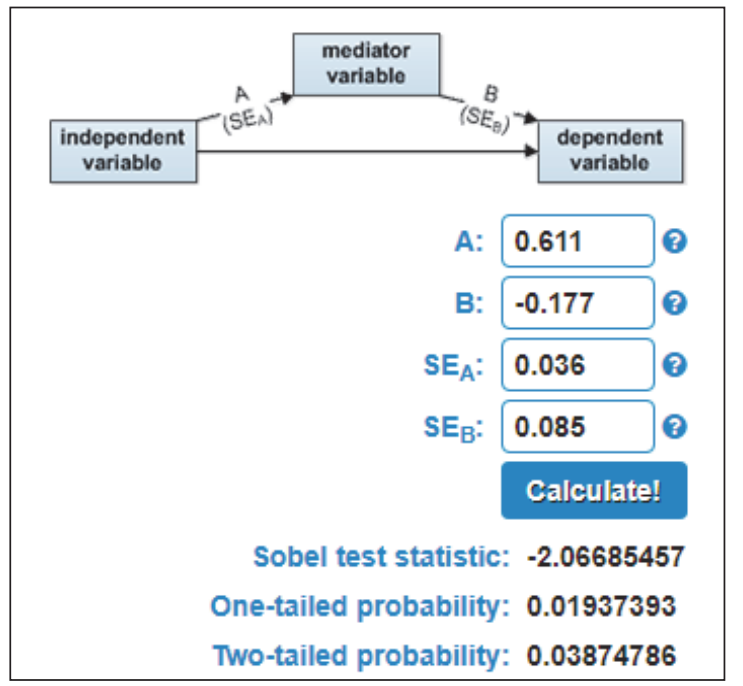

Fig. 2. Sobel Test Results Hypothesis 6

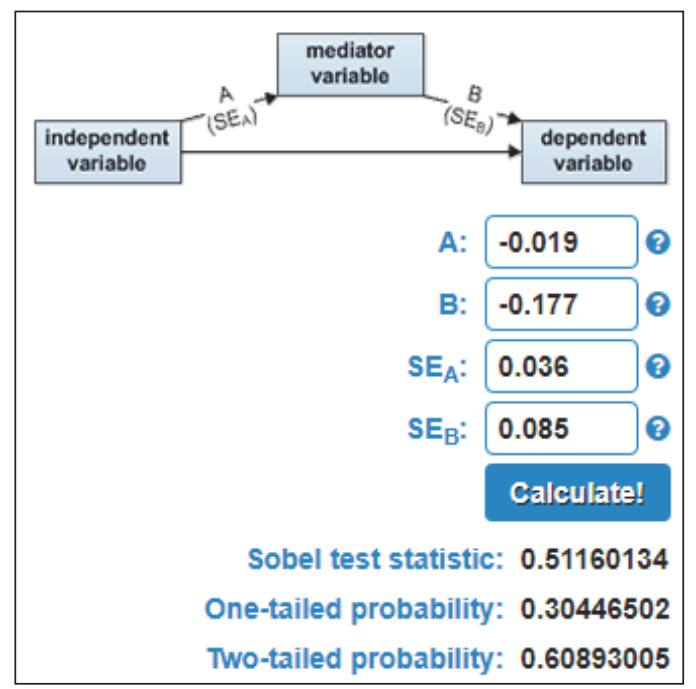

Fig. 3. Sobel Test Results Hypothesis 7

Fig. 2 shows that the probability value of 0.01937393 is smaller than 0.05 with a Sobel value of 2.067 negative, meaning that religious control was able to mediate the influence of professional commitment to reduce auditor turnover; thus hypothesis 6 was accepted. Auditors holding professional commitments and were able to increase religious control would continue working or not leave. This finding was also consistent with the results of the hypotheses 1 and 5 tests that are significant. 
Fig. 3 shows that the probability value of 0.30446502 is greater than 0.05 and the Sobel value is positive at 0.511 . These values suggested that the religious control did not mediate the influence of the organizational commitment on the auditor turnover; thus hypothesis 7 was rejected. Auditors who had the organizational commitments and were able to increase their religious control had an increase desire to change jobs; although, it was not significantly. This was in accordance with the results of the tested hypothesis 2 that was rejected and hypothesis 5 that was accepted; so that, the multiplication of the regression coefficient produced a result that was not significant or rejected.

\section{Conclusion}

The conclusion of this study is that religious control can reduce auditor turnover directly and can mediate the effect of professional commitment on auditor turnover. Professional commitment and organizational commitment are not able to reduce auditor turnover, and religious control is not able to mediate the influence of organizational commitment on auditor turnover. The theoretical implications of this research enrich the behavioral accounting and auditing literature by providing empirical evidence regarding the role of religious control in reducing auditor turnover. Meanwhile, the practical implications provide consideration to PAF leaders in reducing auditor turnover through religious control. However, this study has limitations in revealing and unable to answer the reasons for auditor either to stay or leave the organization. Therefore, future studies are suggested to further explore the related issue by both questionnaires and interviews; in the hope that the results of the research will be more in-depth and comprehensive.

\section{References}

Alfan, M. (2013). Introduction to Value Philosophy. Bandung: Pustaka Setia.

Aranya, N., Pollock, J., \& Amernic, J. (1981). An examination of professional commitment in public accounting. Accounting, Organizations and Society, 6(4), 271-280.

Aries, I. S., \& Ghozali, I. (2006). Behavioral Accounting-Concepts and Empirical Studies of Behavior of Accountants. Semarang: Diponegoro University Publishing Agency.

Bagraim, J. (2003). The dimensionality of professional commitment. SA Journal of Industrial Psychology, $29(2), 6-9$.

Cannon, N. H., \& Herda, D. N. (2016). Auditors' organizational commitment, burnout, and turnover intention: A replication. Behavioral Research in Accounting, 28(2), 69-74.

Carter, E., McCullough, M., \& Carver, C. (2012). The mediating role of monitoring in association of religion with self-control. Social Psychological and Personality Science, 3(6), 691-697.

Cohran, J. (1988). The Effect of Religiosity on Secular and Ascetic Deviance. Sociological Focus, 21(4), October, 293-306,

Cook, J., \& Wall, T. (1980). New work attitude measures of trust, organizational commitment and personal need non-fulfilment. Journal of Occupational Psychology, 53, 39-52.

Danuri, M., \& Sulistiyo, H. (2017). Religious cyber as controller of amoral behavior of computer users. Infokam, 8(1), March, 23-32.

Desmond, S., Ulmer \& Bader. (2013). Religion, self-control, and substance use. Deviant Behavior, 34(5), $384-406$.

Ghozali, I. (2011). Multivariate Applications with IBM SPSS 19. Semarang: Diponegoro University Publishing Agency.

IAPI. (2016). Directory of Public Accountants - IAPI .

Jannah, B.S., Baridwan, Z., \& Hariadi, B. (2016). The determinant of auditors turnover intention from public accounting firm. Imperial Journal of Interdisciplinary Research (IJIR), 2(2), 537-.

Lampe, J.C, \& Earnest, K.R (1984). How motivation effects accountants productivity and turnover. Management Accounting, 65(8), February, 50-55.

Lim, A.J.P, Loo, J.K, \& Lee, P.H (2017). The impact of leadership on turnover intention: The mediating role of organizational commitment and job satisfaction. Journal of Applied Structural Equation Modeling, 1(1), June, 27-41.

Mathieu, J. E., \& Zajac, D. M. (1990). A review and meta-analysis of the antecedents, correlates, and consequences of organizational commitment. Psychological Bulletin, 108(2), 171.

Muthuveloo, R., \& Che, R.R (2005). Typology of organizational commitment. American Journal of Applied Science, 2(6), 10781081.

Nouri, H., \& Parker, J.R (2013). Career growth opportunities and employee turnover intentions in public accounting firms. The British Accounting Review, 45, 138-148.

Parliament of the World's Religions. (1993). Declaration of Toward a Global Ethic, September, Chicago, USA, 1-15.

Rageb, A.M, Salam, A.E.M, Samadicy, A.E, \& Farid, S. (2013). Organizational commitment, job satisfaction and job Performance as a mediator between the role stressors and turnover intentions: a study of Egyptian cultural perspective. International Journal of Business and Economic Development, 1(1), March, 34-54.

Ratnawati, V. (2001). The effect of antecedent factors, job insecurity, and its consequences on the desire to switch employees: An empirical study at the Indonesian public accounting firm. National Accounting Symposium IV, Indonesian Institute of Accountants, 411-428. 
Robbins, P.S., \& Judge, A.T. (2013). Organizational Behavior. (15th Ed.). New Jersey: Pearson Prentice Hall.

Scholl, R. (1981). Differentiating organizational commitment from expectancy as a motivating force. The Academy of Management Review, October 1981, 6(4), 589-599.

Shyam, K.F., David, W., \& Zafer, E. (2002). The influence of religion on attitudes toward the advertising of controversial products. European Journal of Marketing, 38 (5/6), 537-555.

Snead, K., \& Harrell, A. (1991). The impact of psychological factors on the job satisfaction of senior auditors. Behavioral Research in Accounting, 3, 85-96.

Sow, M.T. (2015). Relationship Beetween Organizational Commitment and Turnover Intentions among Healthcare Internal Auditors, Walden Dissertations and Doctoral Studies, Walden University

Suddaby, R., Gendron, Y., \& Lam, H. (2009). The organizational context of professionalism in accounting. Accounting, Organizations and Society, 34(3-4), 409-427.

Sulistiyo, H. (2016). Analysis of the Effect of Control Locus, Professional Commitment, and Independence on Dysfunctional Audit Behavior Mediated by Organizational Commitment and Moderated By Religious Control (Empirical Study on Public Accounting Firms in Indonesia), (Dissertation of doctorate in economics), Diponegoro University, Semarang.

Sulistiyo, H. (2017). Auditor's public accountant office turnover study in Indonesia by gender, education level, position and city. Journal of Economic Management and Accounting, 43(24), October, 49-58.

Sulistiyo, H., \& Ghozali, I. (2017). The role of religious control in dysfunctional audit behavior: An empirical study of the auditors of public accounting firms in Indonesia. The Journal of Applied Business Research, 33(5), September / October, 1047-1058.

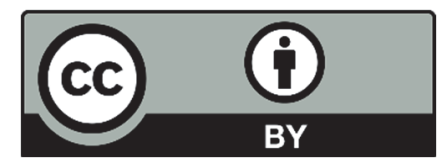

(C) 2020 by the authors; licensee Growing Science, Canada. This is an open access article distributed under the terms and conditions of the Creative Commons Attribution (CC-BY) license (http://creativecommons.org/licenses/by/4.0/). 